\title{
Resensie-artikel
}

\section{Postmodernistiese opstandings(on)geloof?}

Müller, Julian. 2006. Opstanding. Wellington: Lux Verbi.BM. 128 p. Prys: R69,95. ISBN: 0796304092.

B.J. van der Walt

Skool vir Filosofie

Potchefstroomkampus

Noordwes-Universiteit

POTCHEFSTROOM

\section{Inleiding}

Die skrywer begin (p. 8) met 'n vraag wat tydens 'n program op RSG aan hom gestel is, naamlik "Glo jy in die histories-fisieke opstanding van Christus?" Hierop kon hy nie duidelik met 'n "Ja" of "Nee" antwoord nie. Hy het slegs gesê dat hy dié Sondagoggend nog saam met die ander gelowiges in die kerk bely het dat hy "glo in Christus wat op die derde dag weer uit die dood opgestaan het".

Die rede waarom hy nie volmondig "Ja" kon sê nie, was omdat die manier waarop die vraag aan hom gestel is volgens hom 'n soort teologie veronderstel wat hy nie kan onderskryf nie (p. 9). Hy wil in dié boek nie 'n stuk dogmatiek oor die opstanding skryf nie, maar eerder 'n "persoonlike refleksie" (p. 11), want vir hom is 'n persoonlike ontmoeting met die opgestane Here belangriker as ' $n$ logiese verstaan van die opstanding. Weinig Christene sal nie met laasgenoemde woorde volmondig instem nie.

Die groot vraag is egter - en dit sal telkens na vore tree - of 'n mens in lemand (Christus) of iets (sy opstanding) kan glo sonder om te weet waarin jy glo; sonder om 'n bepaalde begrip daarvan te hê. 
Geloof het tog ook 'n logiese faset. (Vgl. die Heidelbergse Kategismus wat geloof beskou as 'n gewisse kennis en vaste vertroue.)

\section{2. 'n Postmodernistiese vertrekpunt}

Ongelukkig toon Müller nie genoeg begrip vir die feit dat 'n bepaalde filosofie op 'n fundamentele wyse 'n mens se teologie bepaal nie. Dit kan selfs die Bybelse aard daarvan grondig aantas.

Dwarsdeur sy boek kruis hy swaarde met die rasionalistiese ortodoksie, omdat dit alles - ook iets so onbegrypliks soos die opstanding - wil verstaan. Ongelukkig word die (ouere) rasionalistiese filosofie in sy denke bloot ingeruil vir die (nuutste) irrasionalistiese postmodernisme. Dié proses waarin 'n oudmodiese filosofie met 'n modefilosofie vervang word, is tipies van die hele 2000-jarige geskiedenis van die teologie. Net so ook die onkritiese houding teenoor die kontemporêre filosofie.

Volgens Müller het elke tyd sy eie filosofie en dit is nooit net goed of sleg vir die evangelie en die kerk nie (p. 99). Daarom kan hy die postmodernisme feitlik kritiekloos aanvaar: Ons geloofstaal moet só verwoord word dat dit getrou is aan die postmoderne lewensgevoel wat ons nie kan ontsnap nie (p. 100). Later (p. 114) stel hy as die doel van sy boek om sy geloof in die opstanding van Christus nuut te verwoord en uitdrukking te gee aan sy eie opstandingsgeloof in hierdie postmoderne tyd (kursivering bygevoeg - BJvdW).

Omdat hy egter besef dat die postmodernisme alles bevraagteken en onseker maak, water hy dié standpunt later effens af deur te sê dat daar ten minste raakvlakke tussen die evangelie en die postmodernisme is (p. 103).

Die volgende tipiese trekke van die postmodernisme kom in hierdie boek na vore: irrasionalisme, subjektivisme, metaforiese denke en relativisme. Hoewel die boek ook vanuit ander hoeke beskou en beoordeel mag word, word die aandag hier op die sterk postmodernistiese inslag - en die gevare daaraan verbonde gevestig.

\section{Irrasionalisme}

Soos reeds gesê, verwerp die skrywer dwarsdeur sy werk (bv. p. 42) die rasionalisme van die modernisme, omdat dit die geloof logies wil vaslê en voorskryf en nie plek vir persoonlike belewenis laat nie. 
Postmoderniste se klem op relativiteit, onsekerheid, verbeelding en verwondering kan ons dus help om die evangelie te beleef. Want dit word by herhaling gesê - vir hom is die primêre vraag nie hoe verstaan 'n mens die opstanding nie, maar hoe beleef jy dit (p. 48). Teenoor die ou ortodoksie (regte leer) moet daar 'n nuwe ortopraksie (regte lewe) kom.

Natuurlik is Müller reg as hy sê die opstandingsevangelie is veel belangriker as die leerstuk oor die opstanding. Myns insiens trap hy hier egter in die eeu-oue slagyster van leer of lewe. Die twee is volgens my onskeibaar verbonde en ewe belangrik.

Indien Müller konsekwent irrasionalisties gedink het, sou hy nie die boekie kon skryf waarin hy - op logiese wyse - sy gedagtes uiteensit nie, maar moes hy swyg. Al verskil hy ook van die sogenaamde ortodoksie, kan hy nie anders as om te sê wat hyself onder die opstanding verstaan nie. Hy kan nie bloot glo nie, maar moet sê wat/waarin hy glo.

Dit is byvoorbeeld waar wat hy sê, naamlik dat God nie in enige stelling, sisteem of logiese struktuur ingeperk kan word nie (p. 63). Maar terselfdertyd kon hy nie daaraan ontkom om op 'n bepaalde manier oor God te dink nie!

\section{Geloof en wete(nskap)}

Müller verwerp die standpunt van die Evangeliese fundamentaliste, omdat hulle (volgens hom onder invloed van 'n modernistiese wetenskapsideaal) 'n logiese greep op die opstanding probeer kry, deur te sê dat Christus histories-fisiek opgestaan het.

Hy wil dus ook nie saamgaan met die mense van die Jesus Seminaar (in Suid-Afrika die "Nuwe Hervormers" genoem), wat twyfel of Christus uit 'n maagd gebore en op die derde dag opgestaan het nie. Volgens hom laat ook hulle modernistiese wetenskap hulle nie toe om te glo nie.

Müller wil (weens sy "metaforiese" geloof - sien later) egter nie beskuldig word van 'n sacrificium intellectus (kruisiging van die verstand) nie (p. 73). Hy wil, soos hy sê, 'n weg vind om as rasionele wese ook godsdienstig te kan wees (p. 74). Sy oplossing vir hierdie valse - en reeds eeue oue - geloof-wete-dilemma, is die bekende Augustiniaanse credo ut intelligam (ek glo, sodat ek kan verstaan) (p. 68). Dit is egter bloot die teenoorgestelde as die 
rasionalistiese "ek weet, sodat ek kan glo" en bied geensins 'n oplossing nie.

Omdat Müller met die geloof begin, kan hy egter die klem lê op die misterie van die opstanding. Die groot vraag is egter of sy geloof en wete(nskap) of teologie nie in ' $n$ fundamentele spanning met mekaar staan nie: in die kerk kan hy bely dat Christus opgestaan het (vgl. hierbo), maar sy postmodernisties-gekleurde teologie leer dat die opstanding slegs metafories verstaan mag word!

Müller se dilemma (vgl. byvoorbeeld p. 88) is dus dat hy aan die een kant gelowig wil vashou aan die wonderkarakter van die maagdelike geboorte, opstanding, hemelvaart en wederkoms van Christus - dinge wat die verstand te bowe gaan - en tog daaroor wil nadink en wel in terme van die postmodernisme. Die vraag is of dit moontlik is. Bots sy postmodernisties-gekleurde teologie nie grondig met die Bybelse boodskap nie?

\section{Subjektivisme}

Die postmodernisme leer dat objektiwiteit nie bereikbaar is nie. "Al waarop 'n mens kan staatmaak is die hoogste mate van subjektiewe integriteit" (p. 21). Volgens Müller is Christus se opstanding 'n metafoor vir nuwe lewe in onsself (later meer oor die metaforiese aard van die geloof). Daar moet dus tekens in jou wees dat God 'n nuwe begin in jou daaglikse lewe gemaak het (p. 120); dat die opgestane Here ook in ons opgestaan het (p. 128). Natuurlik kan Christus se opstanding dit ook beteken. Maar as dit al is wat sy opstanding inhou, word ons eenvoudig aan subjektivisme uitgelewer. Impliseer sy standpunt byvoorbeeld dat as ons nie in onsself tekens van 'n nuwe lewe sien nie, Christus nie opgestaan het nie?

\section{Metaforiese denke}

Volgens die skrywer moet ons geloof "verhalend en metafories" verwoord word (p. 26). Die "metafories-figuurlike" verstaan van Christus se opstanding sou ook nie afbreek doen aan die historiese (feitelikheid) nie, maar bou daarop en bring dit (die opstanding) nader aan ons (p. 31, 32).

Wat hy presies met "metafories" bedoel, blyk daaruit dat (1) Christus nie net opgestaan het nie, maar soos reeds gesê (2) ín ons opgestaan het en ons tot 'n nuwe lewe opwek (p. 32). 
My probleem lê nie by (2) nie, maar by (1). Miskien glo Müller wél in die opstanding, maar of hy dit in sy teologie leer, is nie duidelik nie. (Vgl. sy geloofwete-dilemma, soos reeds bespreek.) As (1) nie histories waar is nie, kom ook (2) dan nie op losse skroewe te staan nie?

Anders gestel: Is dit nodig om van die opstanding van Christus 'n metafoor te maak om dit persoonlik te kan maak? (Vgl. byvoorbeeld die Heidelbergse Kategismus, vraag en antwoord 45: "Watter nut het die opstanding van Christus vir ons?")

Later in die boek word die geloof in Christus se opstanding nog verder tot slegs 'n "simbool" afgewater (p. 105). Daar mag dus nie voorgeskryf word wat die presiese inhoud van dié geloof vir iemand moet wees nie (p. 105). Die skrywer vergeet blykbaar dat hy met so 'n stelling - ook al is dit negatief - tog ook voorskryf hoe dié geloof verstaan moet word. Die enigste vraag is: Watter betekenis het die geloof vir jou (p. 106) of: Hoe beleef jy dit? (p. 117). Die postmodernistiese subjektivisme loer hier weer om die hoek.

\section{Relativisme}

Hierdie subjektivisme lei ook tot relativisme. Müller wil nie as 'n ortodokse fundamentalis beskou word nie en ook nie as 'n verteenwoordiger van die Nuwe Hervorming nie. Sy eie standpunt is egter nie duidelik nie - tipies postmodernisties. Blykbaar kom sy standpunt daarop neer dat solank 'n mens se geloof in Christus se opstanding vir hom-/haarself iets beteken, dit in orde is. Verskillende standpunte is dus welkom.

In dié lig moet 'n mens heelwaarskynlik ook verstaan waarom die skrywer so 'n groot verskil maak tussen die opstanding van Lasarus en dié van Christus. Natuurlik is daar verskille - Christus was God en sou ook nie, soos Lasarus, weer sterf nie. Maar is die verskil ook dat Lasarus histories-fisiek opgestaan het en Christus se opstanding in totale misterie gehul is (p. 97), sodat sy opstanding net metafories of figuurlik verstaan moet word?

Hoe weet Müller dat die opstanding van Christus so onbegryplikmisterieus van aard was dat hy nie "histories-fisiek" opgestaan het nie? Het Christus nie ook as mens, met ander woorde historiesfisiek opgestaan nie? Die dissipels en vroue kon Hom tog herken en Thomas kon die merke in sy voete en hande sien en tas. 
Ook al wil Müller nie met die Nuwe Hervorming vereenselwig word nie, bied sy teologie geen vaster grond vir ons geloof nie. Met sy omarming van die postmodernistiese irrasionalisme, subjektivisme en relativisme skiet hy homself uiteindelik self in die voet!

'n Laaste vragie is die volgende: Lê die waarborg dat ook ons eendag uit ons grafte sal opstaan nie juis in die histories-fisiese nie?; dit wil sê in die werklike en nie bloot die metaforiese/figuurlike/ simboliese opstanding van Christus nie? In die Skrif bestaan daar 'n onlosmaaklike verband tussen Christus se opstanding en ons opwekking op die laaste dag: "Want as die dode nie opgewek word nie, dan is Christus ook nie opgewek nie; en as Christus nie opgewek is nie, dan is julle geloof nutteloos ..." (1 Kor. 15:16, 17; vgl. ook die vorige en daaropvolgende verse.)

Waarom sê Müller in sy boek niks oor ons opstanding nie? Is dit dalk ook - net soos die opstanding van Christus - bloot 'n metafoor, of simbool en nie 'n werklikheid nie?

\section{Gevolgtrekking}

Ek het - met groot verwagting - gedurende die Paastyd hierdie boek begin lees, want dit gaan oor 'n uiters belangrike saak - die hart van die Christelike geloof. Ek sou graag in die lig van sy boek my eie opstandingsgeloof wou ondersoek en verryk. Maar in plaas van om daardeur gestig te word (in die geloof versterk te word) is ek eerder ontstig. Indien 'n mens graag wil weet hoe 'n postmodernistiese teologie ' $n$ fundamentele Bybelse waarheid soos Christus se opstanding op subtiele wyse bevraagteken, lees dan hierdie boek.'n Mens kan slegs raai watter lot ander grondliggende waarhede soos skepping, sondeval, verlossing en voleinding sal tref. Indien u egter wil weet en bly glo wat God se Woord self oor die opstanding leer, kan u gerus hierdie postmodernistiese opstandings (on)geloof sonder enige skade ignoreer. Dié boek propageer (in die gedaante van 'n Christelike teologie) eerder 'n sekulêre filosofie en bied nie 'n bydrae tot 'n beter begrip van Christus se opstanding en die betekenis daarvan vir ons as gelowiges nie.

'n Mens kan dus goed begryp (vgl. die begin van hierdie artikel) waarom Müller nie volmondig "Ja" kon antwoord op die vraag of Christus werklike (histories) en liggaamlik (fisiek) uit die graf opgestaan het nie. 


\section{Naskrif}

Myns insiens is sowel die (ouere) modernisties-rasionalistiese fundamentalisme as die (hedendaagse) postmodernistiese irrasionalisme die verkeerde oplossings vir die probleem - die probleem oor wat die verskille en verhouding is tussen God se openbaring en ons feilbare menslike verstaan daarvan. Ruimte om hier aan te toon hoe albei dwaalweë vermy kan word, ontbreek ongelukkig. 
